\title{
Hubungan antara Status Gizi dan Sistem Imun Seluler pada Subyek Penyakit Ginjal Kronik Stadium V Hemodialisis di Instalasi Tindakan Hemodialisis RSUP Prof. Dr. R. D. Kandou Manado
}

\author{
${ }^{1}$ Julyan V. Unawekla \\ ${ }^{2}$ Emma Sy. Moeis \\ ${ }^{3}$ Yuanita A. Langi
}

\author{
${ }^{1}$ Program Studi Pendidikan Dokter Fakultas Kedokteran Universitas Sam Ratulangi Manado \\ ${ }^{2}$ Bagian Ilmu Penyakit Dalam Fakultas Kedokteran Univrsitas Sam Ratulangi Manado \\ Email: julyanviko07@gmail.com
}

\begin{abstract}
Chronic kidney disease (CKD) is a pathophysiological process with a diverse etiology that causes progressive decrease of renal function and is generally ended with renal failure. Patients with CKD are given low-protein and low-water diets that can affect their nutritional status and immune system. This study was aimed to determine the relationship between nutritional status and cellular immune system in patients with stage V CKD that had hemodialysis perfomed on them at the Installation of Hemodialysis of Prof. Dr. R. D. Kandou Hospital Manado. This was a descriptive analytical study with a cross sectional design. Variables were age, gender, lymphocyte count, body mass index (BMI), and upper arm circumference. There were 30 samples in this study; males (56.7\%) were more dominant. The age range was 36-76 years; lymphocyte count range was 1000-4131; IMT range was 16-28.1; and upper arm circumference range was 17-28.50. The Spearman parametric test of the relationship between nutritional status and cellular immune system based on BMI and lymphocyte count obtained a $P$-value of 0.111 meanwhile the relationship between nutritional status based on upper arm circumference and lymphocytes obtained a $P$-value of 0.309 . Conclusion: There was no relationship between nutritional status (BMI and arm circumference) and cellular immune system (lymphocyte count) in stage V CKD patients that had hemodialysis perfomed on them.
\end{abstract}

Keywords: CKD V-HD, nutritional status, cellular immune system

\begin{abstract}
Abstrak: Penyakit ginjal kronik (PGK) adalah suatu proses patofisiologis dengan etiologi beragam yang mengakibatkan penurunan fungsi ginjal secara progesif dan umumnya berahir dengan gagal ginjal. Pasien PGK diberikan terapi rendah protein dan air sehingga dapat berdampak pada status gizi dan sistem imun pasien. Penelitian ini bertujuan untuk mengetahui hubungan status gizi dengan sistem imun seluler pada subyek PGK stadium V hemodialisis di Instalasi Tindakan Hemodialisis RSUP Prof. Dr. R. D. Kandou Manado. Jenis penelitian ialah deskriptif analitik dengan desain potong lintang. Variabel penelitian ialah usia, jenis kelamin, hasil hitung limfosit, hitung IMT, dan ukuran lingkar lengan atas (LILA). Hasil penelitian mendapatkan 30 sampel dengan jumlah terbanyak ialah laki-laki 17 orang $(56,7 \%)$, cengan rentang usia 36-76 tahun. Kisaran nilai untuk limfosit ialah 1000-4131; IMT 16-28,1; dan LILA 17-28,50. Uji parametrik Spearman terhadap hubungan antara status gizi berdasarkan IMT dan limfosit mendapatkan $P=0,111$ sedangkan antara status gizi berdasarkan LILA dan limfosit mendapatkan $P=0,309$. Simpulan: Tidak terdapat hubungan antara status gizi (IMT dan LILA) dengan limfosit (sistem imun) pada pasien PGK V yang menjalani hemodialisis.
\end{abstract}

Kata kunci: PGK V-HD, status gizi, sistem imun seluler 
Penyakit ginjal kronik (PGK) adalah suatu proses patofisiologi dengan etiologi beragam yang mengakibatkan penurunan fungsi ginjal yang progresif dan umumnya berakhir dengan gagal ginjal. Pada gagal ginjal terjadi kerusakan faal ginjal yang bersifat menahun (kronik), progresif, dan ireversibel. Pada suatu tahap gagal ginjal diperlukan terapi pengganti ginjal yang tetap berupa dialisis atau transplantasi ginjal. ${ }^{1}$

Patofisiologi PGK awalnya tergantung pada penyakit yang mendasarinya. Pengurangan massa ginjal mengakibatkan hipertrofi struktural dan fungsional nefron yang masih berfungsi sebagai upaya kompensasi yang diperantarai oleh molekul vasoaktif seperti sitokin dan growth factor. Penyebab PGK dapat disebabkan oleh beberapa faktor, antara lain: usia, diabetes melitus (DM), hipertensi, dan penyalahgunaan obat-obatan analgetik dalam jangka waktu yang lama. ${ }^{1-3}$ Perhimpunan Nefrologi Indonesia (PENEFRI) tahun 2000 mencatat penyebab gagal ginjal pada pasien yang menjalani hemodialisis di Indonesia ialah glomerulonefritis $46,39 \%$, diabetes melitus $18,65 \%$, obstuksi dan infeksi $12,85 \%$, dan hipertensi 8,46\%. ${ }^{1}$ Pada tahun 2011 PERNEFRI mencatat penyebab gagal ginjal karena DM 23\%, hipertensi 46\%, penyakit kardiovaskuler $11 \%$, penyakit serebrovaskuler $2 \%$, penyakit saluran cerna $2 \%$, penyakit saluran kencing $3 \%$, tuberkulosis $1 \%$, hepatitis B $2 \%$, hepatitis C $2 \%$, keganasan $4 \%$, dan penyebab lainnya yang belum diketahui $5 \%{ }^{2}$

Pada pasien dengan laju filtrasi glomerulus (LFG) $<60 \mathrm{ml} / \mathrm{mnt} / 1,73 \mathrm{~m}^{2}$ dilakukan pembatasan asupan protein yaitu diberikan $0,6-0,8 / \mathrm{kg} / \mathrm{BB} / \mathrm{hari}$ dan jumlah kalori sebesar 30-35 kkal/kgBB/hari. Hal ini bertujuan untuk menghambat perburukan fungsi ginjal yang disebabkan oleh hiperfiltrasi glomelurus. Diet tinggi protein akan mengakibatkan gangguan klinis dan metabolik yang disebut uremia dan progresivitas kerusakan ginjal meningkat. Pembatasan asupan protein juga dapat berdampak pada status gizi pasien PGK yang rentan mengalami gizi kurang.
Tindakan terapi pengganti ginal dilakukan ketika LGF $<15 \mathrm{ml} / \mathrm{mnt} / 1,73 \mathrm{~m}^{2}$ yang dapat berupa hemodialisis atau transplantasi ginjal. Tindakan ini dilakukan ketika pengobatan konservatif yang berupa diet, pembatasan minum dan obat-obatan tidak mampu memperlambat pemburukan fungsi ginjal sehingga kerusakan nefron sudah mencapai $70 \%$ atau lebih. ${ }^{1}$

Hemodialisis merupakan terapi pengganti fungsi ginjal yang bertujuan untuk mengeluarkan sisa metabolisme protein atau mengoreksi gangguan keseimbangan air dan elektrolit antara darah dengan dialisat melalui membran semipermeable. ${ }^{1,4}$

Sistem imun tubuh memiliki fungsi membantu perbaikan DNA dan mencegah infeksi di dalam tubuh yang disebabkan oleh jamur, bakteri, dan virus, serta menghasilkan antibodi. ${ }^{5}$ Limfosit ialah salah satu jenis dari leukosit yang berfungsi sebagai sistem imun. Dalam keadaan normal jumlah limfosit mencapai 20-50\% dari sel darah putih dalam aliran darah. ${ }^{6}$ Secara umum limfosit mempunyai dua fungsi utama yaitu sebagai pembunuh antigen yang masuk dalam tubuh dan sebagai pengenal antigen yang sama masuk kembali ke dalam tubuh. Terdapat dua jenis limfosit yaitu limfosit sel $\mathrm{T}$ dan limfosit sel B. Keduanya dibentuk dalam sumsum tulang dan bermigrasi ke jaringan limfoid seperti kelenjar timus, limpa, kelenjar limfatik, permukaan mukosa saluran napas, dan permukaan mukosa saluran cerna. Limfosit sel $\mathrm{T}$ mempunyai proporsi lebih banyak dalam limfosit yaitu sekitar $75 \%$ dan terdiri antara lain dari limfosit sel $\mathrm{T}$ helper dan limfosit sel T-killer. Limfosit B berfungsi untuk menghasilkan antibodi imunoglobulin seperti $\operatorname{IgA}, \operatorname{IgG}, \operatorname{IgE}$, dan IgD setelah diaktifkan oleh sel T-helper. ${ }^{7}$ Sistem imun terbagi atas dua yaitu sistem imun humoran dan sistem imun selular. ${ }^{8}$

Status gizi adalah keadaan tubuh yang merupakan hasil akhir dari keseimbangan antara zat gizi yang masuk dan penggunaannya. Status gizi yang baik juga mendukung kualitas hidup pasien menjadi lebih baik. Pasien PGK rentan mengalami gizi kurang sehingga dapat menyebabkan berat 
badan dan sistem imun menurun karena pada pasien PGK diberikan diet rendah protein, natrium, vitamin, dan air untuk mencegah terjadinya uremia di dalam darah. ${ }^{4,9}$ Status gizi terbagi atas tiga bagian, yaitu status gizi baik, status gizi kurang dan status gizi lebih. Penilaian status gizi pada pasien PGK V- HD dapat dilakukan dengan pengukuran antropometri yang secara umum digunakan untuk melihat ketidakseimbangan asupan protein dan energi. Antropometri gizi berhubungan dengan berbagai macam pengukuran dimensi tubuh untuk semua tingkat usia. Pengukuran antropometri yang dapat dilakukan ialah dengan mengukur lingkar lengan atas (LILA) dan menghitung IMT. ${ }^{10}$

Penelitian ini bertujuan untuk mengetahui hubungan antara status gizi dan sistem imun seluler pada pasien PGK stadium V-HD di Instalasi Tindakan Hemodialisis RSUP Prof. Dr. R. D. Kandou Manado.

\section{METODE PENELITIAN}

Jenis penelitian ini ialah deskriptif analitik dengan desain potong lintang dan menggunakan uji parametrik Spearman. Penelitian dilakukan di Instalasi Tindakan Khusus Unit Hemodialisis Ruangan Melati RSUP Prof. Dr. R. D. Kandou sejak Desember 2014 sampai Januari 2015. Sampel yang diambil ialah pasien PGK stadium V-HD dengan hemodialisis dua kali dalam satu minggu selama 4-5 jam. Variabel penelitian yang ambil yaitu usia, jenis kelamin, hitung limfosit, hitung IMT, dan ukuran LILA.

Data diperoleh melalui pengukuran langsung IMT dan LILA, serta pengambilan darah untuk hitung limfosit pada pasien PGK V-HD di Ruangan Melati RSUP Prof. Dr. R. D. Kandou.

\section{HASIL PENELITIAN}

Hasil penelitian ini mendapatkan sebanyak 30 pasien PGK V-HD, terdiri dari 17 orang laki-laki $(56,7 \%)$ dan 13 orang perempuan $(43,3 \%)$.

Pada rentang usia pasien didapatkan nilai minimum 36 tahun dan nilai maksi- mum 76 tahun. Pada rentang nilai IMT didapatkan nilai minimum 16 dan nilai makimum 28. Pada rentang nilai LILA didapatkan nilai minimum 17 dan nilai maksimum 28,50. Pada rentang nilai hitung limfosit didapatkan nilai minimum 1000 dan nilai maksimum 4131 (Tabel 1).

Tabel 1. Rentang variabel usia, IMT, LILA, dan hitung limfosit

\begin{tabular}{cccc}
\hline & Min & Maks & SD \\
\hline Usia & 36,00 & 76,00 & 11,33 \\
IMT & 16,00 & 28,10 & 3,39 \\
LILA & 17,00 & 28,50 & 2,04 \\
Limfosit & 1000,00 & 4131,0 & 756,47 \\
\hline
\end{tabular}

Berdasarkan nilai IMT didapatkan status gizi normal sebanyak 13 pasien $(43,3 \%)$, status gizi kurang 10 pasien $(33,3 \%)$, risiko obesitas 4 pasien $(13,3 \%)$ dan obesitas 3 pasien (10\%) (Gambar 1).

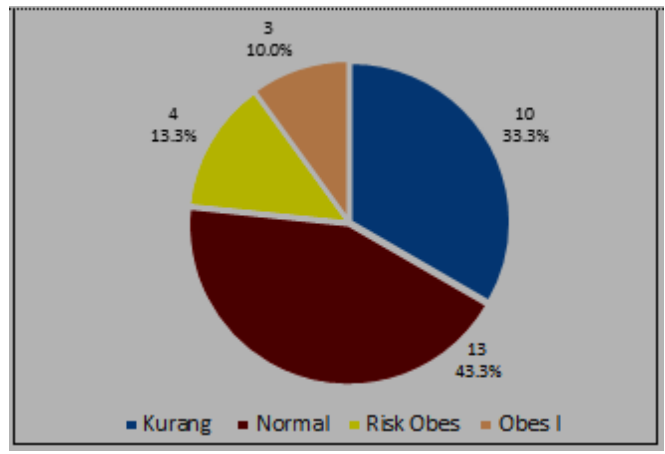

Gambar 1. Grafik distribusi gizi pasien berdasarkan IMT

Uji parametrik Spearman dilakukan untuk menganalisis hubungan status gizi berdasarkan IMT dengan limfosit (Gambar 2).

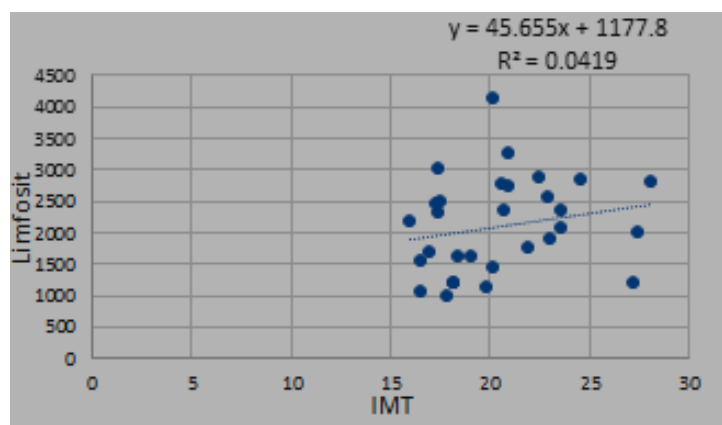

Gambar 2. Grafik hubungan IMT dan limfosit 
Hasil analisis uji Spearman menunjukkan nilai koefisien korelasi r sebesar 0,297 yang menunjukkan interpretasi koefisien korelasi rendah.

Uji parametrik Spearman dilakukan untuk menganalisis hubungan status gizi berdasarkan LILA dengan limfosit (Gambar 3). Hasil analisis uji Spearman menunjukkan nilai koefisien korelasi $r$ sebesar 0,192 yang menunjukan interpretasi koefisien korelasi rendah.

Nilai R Square sebesar 0,0024 dan nilai signifikan $P$ sebesar 0,309 dengan menggunakan $\alpha$ sebesar 5\% $(0,05)$, maka $P=0,309$ $>0,05$ yang menunjukan bahwa tidak terdapat hubungan antara status gizi berdasarkan LILA dan limfosit.

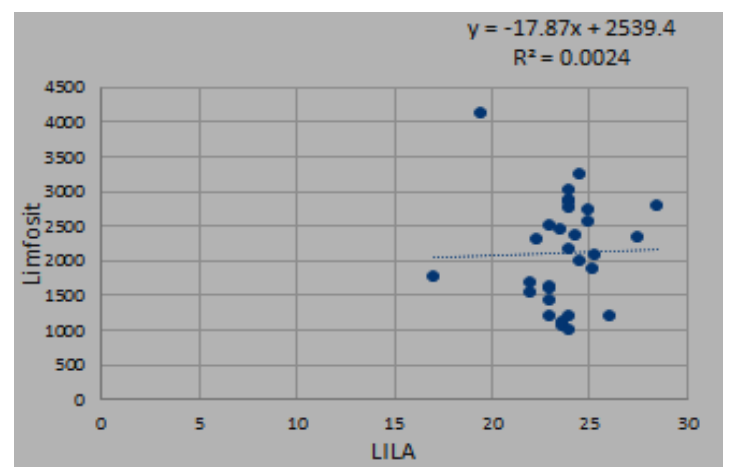

Gambar 3. Grafik hubungan LILA dan limfosit

\section{BAHASAN}

Penelitian ini dilakukan dari bulan Desember 2014 sampai bulan Januari 2015 di ruangan hemodialisis Melati RSUP. Prof. Dr. R. D. Kandou Manado diperoleh 30 pasien yang memenuhi kriteria inklusi dan ekslusi dengan persentase jumlah pasien laki-laki $56,7 \%$, lebih banyak dari pasien perempuan 43,3\%. Banyaknya pasien laki-laki mungkin disebabkan karena umumnya laki-laki lebih sering melakukan aktifitas fisik dibandingkan dengan perempuan dan dipengaruhi oleh faktor gaya hidup seperti merokok dan konsumsi alkohol. Hasil penelitian ini sejalan dengan yang dilaporkan oleh Lipoeto et al. ${ }^{11}$ yaitu dari 30 orang pasien gagal ginjal, terdapat $60 \%$ pasien laki-laki dan $40 \%$ pasien perempuan.

Hasil penelitian ini mendapatkan di ruangan hemodialisis Melati RSUP Prof. Dr. R. D. Kandou Manado, semua pasien PGK V-HD ialah usia dewasa $>30$ tahun. Hasil penelitian ini selaras dengan yang dilaporkan oleh Ratnawati ${ }^{12}$ yang mendapatkan bahwa usia merupakan salah satu faktor penyebab PGK dan $60 \%$ pasien PGK-HD ialah pasien usia dewasa dan lanjut usia. Penurunan fungsi ginjal dalam skala kecil merupakan proses normal seiring bertambahnya usia tetapi tidak menyebabkan kelainan karena masih dalam batas yang normal dan dapat ditoleransi oleh ginjal dan tubuh. Usia merupakan salah satu faktor penurunan fungsi ginjal karena semakin bertambah usia semakin berkurang fungsi ginjal dan berhubungan dengan penurunan kecepatan ekskresi glomeruli dan memburuknya fungsi tubuli ginjal. ${ }^{13}$

Faktor usia juga dapat memengaruhi sistem imun. Kemampuan imunitas kelompok lanjut usia menurun sesuai peningkatan usia termasuk kecepatan respons imun melawan infeksi penyakit ini dikarenakan pada lansia produksi imunoglobulin menurun. ${ }^{5}$

Penelitian ini menggunakan uji parametrik Spearman untuk menganalisis hubungan antara status gizi berdasarkan IMT dan limfosit dengan hasil nilai $P=$ $0,111>0,05)$ sedangkan untuk menguji hubungan antara status gizi berdasarkan LILA dan limfosit mendapatkan $P=0,309$ $>0,05)$. Hasil ini menunjukan bahwa tidak terdapat hubungan antara status gizi (IMT dan LILA) dan sistem imun (limfosit) walaupun zat gizi merupakan salah satu faktor determinan penting dari respon imunitas. Zat gizi berupa vitamin $\mathrm{A}$, vitamin $\mathrm{E}$, vitamin $\mathrm{C}$, Zinc dan zat besi dapat membantu respon imun. Vitamin A berperan penting dalam imunitas nonspesifik melalui pematangan sel-sel $\mathrm{T}$ dan merangsang fungsi sel $\mathrm{T}$ untuk melawan antigen asing. Vitamin $\mathrm{E}$ melindungi sel dari degenerasi yang terjadi pada proses penuaan dan membantu peningkatan respon imun. Vitamin $\mathrm{C}$ meningkatkan kadar interferon dan aktivasi sel imun, meningkatkan aktivitas limfosit dan makrofag serta 
memperbaiki migrasi dan mobilitas leukosit pada infeksi virus, misalnya virus influenza. Zinc secara tidak langsung memengarui fungsi sistem imun melalui peran sebagai kofaktor dalam pembentukan DNA, RNA dan protein sehingga meningkatkan mitosis selular. Zat besi memengaruhi sistem imun humoral dan selular dan menurunkan produksi IL-1. ${ }^{5}$

Hasil penelitian yang dilakukan oleh Pusparini ${ }^{14}$ menyatakan bahwa hemodiaisis dapat berpengaruh pada penurunan respon imun pasien. Berbeda dengan penelitian ini yang dilakukan di dalam ruangan hemodialisis Melati RSUP Prof. Dr. R. D. Kandou Manado. Pasien yang memiliki status gizi kurang mengatakan bahwa tidak ada diet khusus yang dijalani seperti diet rendah protein dan air, bahkan beberapa pasien dapat melakuan aktivitas fisik seperti biasanya tanpa ada keluhan lain. Hal tersebut tidak sejalan dengan teori yang menyatakan bahwa pasien PGK V- HD harus menjalani diet khusus untuk mengurangi beban kerja ginjal dan uremia. ${ }^{1,15}$ Semua pasien PGK V-HD yang diteliti (30 pasien) tidak menjalani diet khusus sehingga tidak memengaruhi hasil pemeriksaan limfosit. Walaupun pasien memiliki status gizi yang berbeda-beda berdasarkan hitung IMT dan pengukuran LILA, sistem imun pasien PGK V-HD pada penelitian ini tetap terjaga. Seperti yang telah dijelaskan bahwa zat gizi (vitamin) yang terdapat di makanan berperan dalam sistem imun sehingga walaupun status gizi pasien termasuk kategori gizi kurang tetapi asupan makanan dan air tidak dikurangi atau dibatasi yang dapat berpengaruh dalam hasil pemeriksaan hitung jenis limfosit sebagai penilaian sistem imun pasien PGK V-HD. ${ }^{16}$

\section{SIMPULAN}

Berdasarkan hasil penelitian dapat disimpulkan bahwa tidak terdapat hubungan bermakna antara status gizi berdasarkan IMT dengan sistem imunitas seluler berdasarkan hitung jenis limfosit pada pasien dan tidak terdapat hubungan bermakna antara status gizi berdasarkan LILA dengan sistem imunitas seluler berdasarkan hitung jenis limfosit pada pasien PGK V-HD di RSUP Prof. Dr. R. D. Kandou Manado.

\section{SARAN}

Perlu adanya perhatian khusus dari keluarga untuk pasien PGK V- HD dalam hal rutinitas menjalani tindakan hemodialisis. Diharapkan pasien PGK V-HD memahami pentingnya asupan nutrisi untuk metabolisme tubuh dan sistem imun.

\section{DAFTAR PUSTAKA}

1. Suwitra K. PGK. In: Sudoyono AW, Setyohadi B, Alwi I, Simadibrata M, Setiati S, editors. Buku Ajar Ilmu Penyakit Dalam Jilid II (4th ed). Jakarta: EGC, 2009; p. 1035.

2. Perhimpunan Nefrologi Indonesia (PERNEFREI). 4 ${ }^{\text {th }}$ Annual Report of Indonesia Renal Registry, 2011.

3. Perhimpunan Nefrologi Indonesia (PERNEFRI). $7^{\text {th }}$ Annual Report of Indonesia Renal Registry, 2014.

4. Zunaya L, Adriani M. Perbedaan asupan asupan makanan dan status gizi antara pasien hemodialisis adekuat dan inadekuat penyakit ginjal kronik. Media Gizi Indonesia. 2013;9:13-9.

5. Fatmah. Respon imun yang rendah pada manusia usia lanjut. Mekar Kesehatan. 2006;10:47-53.

6. Taufik EF. Harrison Endokrinologi dan Metabolisme. Tangerang: Karisma, 2013; p. 66-7.

7. Hasdinah HR, Dewi P, Peristiowati Y, Imam S. Imunologi - Diagnosis dan Teknik Biologi Molekuler. Yogyakarta: Nuha Medika, 2014; p. 3-10.

8. Abbas AK, Lichman AH. Basic Imunology. Philadephia: Saunders, 2009; p.1-4.

9. Herawati DM, Ariyanto EF. Kebijakan medik pada pasien gagal ginjal kronik dengan hemodialisis di RS Hasan Sadikin Bandung. Jurnal Kebijakan Kesehatan Indonesia. 2014;3:66-74.

10. Supariasa D.N, Bachyar B, Fajar I, Penilaian Status Gizi. Jakarta: EGC, 2001.

11. Lipoeto NI, Megasari N, Putra EA. Malnutrisi dan asupan kalori. Majalah Kedokteran. 2006;56:6-13.

12. Ratnawati R. Efektivitas dialiser pada penderita gagal ginjal. Jurnal Ilmiah 
Widya. 2014;2:48.

13. Supadmi W, Pranadari R. Faktor resiko gagal ginjal kronik di unit hemodialisis RSUD Wates Kulon Progo. Majalah Farmaseutik. 2015;11:318.

14. Pusparini. Perubahan respon imun pada penderita gagal ginjal kronik yang menjalani hemodialisis. J Kedokteran Trisakti. 2000;19:115.
15. National Kidney Foundation. K/DOQI Clinical Practice Gudelines for Cronic Kidney Disease: Evaluation, Classification and Stratification. Am J Kidney Dis. 2002;39(2 Suppl1):S4-5

16. Siswanto, Budisetyawati, Fitra E. Peran beberapa zat gizi mikro dalam sistem imunitas. Gizi Indon. 2013;36:57-64. 